Revista de la red interuniversitaria de estudios sobre las literaturas rioplatenses contemporáneas en Francia

$10 \mid 2014$

El XIX en el XX

\title{
Fragmento de Una vaca ya pronto serás (2006)
}

\section{Néstor Ponce}

\section{OpenEdition}

Journals

Edición electrónica

URL: http://journals.openedition.org/lirico/1655

DOI: 10.4000/lirico.1655

ISSN: 2262-8339

Editor

Réseau interuniversitaire d'étude des littératures contemporaines du Río de la Plata

Referencia electrónica

Néstor Ponce, « Fragmento de Una vaca ya pronto serás (2006) », Cuadernos LIRICO [En línea],

10 | 2014, Puesto en línea el 01 marzo 2013, consultado el 21 abril 2019. URL : http:// journals.openedition.org/lirico/1655; DOI : 10.4000/lirico.1655

Este documento fue generado automáticamente el 21 abril 2019.

\section{(c) (i) (9)}

Cuadernos LIRICO está distribuido bajo una Licencia Creative Commons Atribución-NoComercialSinDerivar 4.0 Internacional. 


\title{
Fragmento de Una vaca ya pronto serás (2006)
}

\author{
Néstor Ponce
}

(cero)

(del carné de Felipe Navarro)

1 Durante varios años le eché una mano al sacerdote Giusseppe Berti. Este hombre había venido a Argentina esgrimiendo el hierro incandescente de la fe. Fe que mueve montañas. Esgrimiendo el bastón luminoso de la creencia. La certeza de una misión en la tierra.

2 Durante años, el padre salesiano se dedicó a evangelizar a los indios del sur. Bautizos, casorios, conversiones y reconversiones. Anduvo a caballo por pampas inhóspitas. Se arrebujó en ponchos azules. Fue de toldería en toldería, durmiendo en pulperías piojosas, asistiendo a velorios herejes. Tuvo que dialogar con comerciantes borrachines para negociar transacciones con caciques y capitanejos. Evitar abusos y estafas. Hablar con hombres de mala fe. Comer asado y brindar con grappas ácidas. Tomar mate mirando el cielo del sur.

3 Conoció a un indiecito milagroso y agradecido. Catequizó, educó, enseñó a leer y a escribir. Compartió hasta tal punto la fe, que se confundió con otros curas. Por momentos hablaba, y se sorprendía descubriendo que no era otro el que tomaba la palabra, sino, apenas, él mismo. Creyó morirse un par de veces. Asistió a amaneceres rosados y a atardeceres tintos en sangre. Contó las estrellas acostado en campo raso. En algún momento, ha de haber comprendido la complejidad de la fe. La fuerza de lo inasible. La levedad de la materia. La ligereza del espíritu.

4 No era fácil la vida en Argentina en aquellos años. Nunca lo fue después. Las tierras del sur despertaban codicia. El aura de la civilización alumbraba el destino de la Patria. Berti conoció la apatía oficial, los negociados, las trifulcas entre generales, los acomodos y la vista gorda. La guerra impiadosa. Supo de malones que por donde pasaban instalaban el desierto. De cautivas que mejoraban la raza. De indios con juanetes que se emborrachaban con aguardientes filosas. De ríos cristalinos, de cardales morados, de yeguas despanzurradas. 
5 Aprendió nuestra lengua y, en algún momento, concibió la empresa disparatada e imposible de la escritura. ¿Cómo llegó a tamaña desgracia? ¿Cómo pudo adentrarse en semejante tragedia? ¿Por qué un hombre pierde la objetividad y se mete en el fango de la utopía? ¿Qué ve un cura italiano en la pampa argentina en plena guerra entre indios y blancos?

6 Intuyo que cosas extrañas. Probablemente hasta cosas que uno no ve. Cada tanto venía a visitarme con su libreta descompaginada. ¿Le echa una mirada?, preguntaba con modestia. Al principio la tarea me pareció divertida, pero luego cambié de opinión. No es que me fastidiara, no. Todo lo contrario. Me daba miedo. Berti escribía y su escritura era, si me permiten la definición, peligrosa. Usted corrija, me decía con suavidad.

7 La lectura de las libretas de Berti se me fue haciendo con el tiempo cosa imprescindible. Tal vez empezara a sentirme viejo.

8 Sus entregas eran absolutamente irregulares y el volumen de texto variable. Podía aparecer un día con un fajo de treinta páginas remendadas y desvanecerse por cuarenta y cinco jornadas, para traerme una miserable hojita que desbarajaba de su libreta como quien arranca de cuajo el plano de la Ciudad de los Césares. Dos días después se me apersonaba con cuarenta hojas. A veces, sus ausencias eran tan prolongadas que lo temía muerto, devorado por los cuervos y los gatos monteses en algún bajío sureño. Y de repente surgía resplandeciente, distribuyendo proyectos y confianza en el porvenir, o también sombrío y errabundo, metiendo la cabeza entre los hombros y devolviéndome el mate vacío, sin comentarios.

9 Nunca leía las correcciones en mi presencia. En realidad, tardé en saber que las leía verdaderamente. Hasta que me trajo el manuscrito final. Usted corrija, sin miedo. Me dijo con suavidad, por última vez.

10 En el fondo, durante todos esos años, Berti había concebido el absurdo, el infantil deseo de escribir sobre el sur y sobre los indios. Sobre un indio. Desde los ojos de los indios. Por los ojos. Con los ojos. Para.

11 El abismo era demasiado espectral como para poder alentar cualquier expectativa de éxito. Una aventura descabellada.

12 Poco importa ahora hasta donde llegó su pluma y hasta donde se entroncó con la mía. El que hace malabares con el peligro termina cayéndose en el precipicio. Con algún desbarajuste en la conciencia.

13 En todo caso, ahora me digo, tal vez pecando de vanidad, que se encuentre donde se encuentre, la lectura de esta versión final quizá pudiera servirle para rozar, para entrever al menos, esa cosa pastosa y blanda que llamamos escritura.

La Plata, noviembre de 1917 